\title{
The Complexity and Fragility of Early Iron Age Urbanism in West-Central Temperate Europe
}

\author{
Manuel Fernández-Götz ${ }^{1}$ - Ian Ralston ${ }^{1}$
}

Published online: 5 September 2017

(C) The Author(s) 2017. This article is an open access publication

\begin{abstract}
The development of large agglomerations is one of the most important phenomena in later Eurasian prehistory. In west-central temperate Europe, the origins of urbanism have long been associated with the oppida of the second to first centuries BC. However, large-scale excavations and surveys carried out over the last two decades have fundamentally modified the traditional picture of early centralization processes. New results indicate that the first urban centres north of the Alps developed over time between the end of the seventh and the fifth century BC in an area stretching from Bohemia to southern Germany and Central France. Sites such as the Heuneburg, Závist, Mont Lassois and Bourges produce evidence of a process of differentiation and hierarchization in the pattern of settlement that was concurrently an expression of, and a catalyst for, increasing social inequality. Although contacts with the Mediterranean world would certainly have played a role in such processes, endogenous factors were primarily responsible for the development of these early Central European agglomerations. This paper summarizes recent fieldwork results, showing the heterogeneity and diversity of Early Iron Age central places and outlining their diachronic development. The fragility and ephemeral character of these centres of power and their territories is highlighted. Their demise was followed by a period of decentralization that constitutes a prime example of the non-linear character of history.
\end{abstract}

Keywords Iron Age $\cdot$ Hallstatt period - Urbanization · Social change · Early states

Manuel Fernández-Götz

M.Fernandez-Gotz@ed.ac.uk

Ian Ralston

Ian.Ralston@ed.ac.uk

1 School of History, Classics and Archaeology, University of Edinburgh, William Robertson Wing, Old Medical School, Teviot Place, Edinburgh EH8 9AG, UK 


\section{Cities Before Oppida: Re-assessing the Early Iron Age Evidence}

Studies of urban development and early state formation in temperate Europe traditionally focus on the evidence from the Late Iron Age oppida of the second and first centuries BC. Literary testimonies, whilst inevitably composed by cultural outsiders and to that extent open to charges of cultural bias, provide many indications of the complexity of these indigenous societies, some run by traditional aristocracies or even by kings, and others by elected magistracies (Fernández-Götz 2014a; Verger 2009). The 'top-down' organization of these societies is manifest both in the historical sources and in the archaeological record (Buchsenschutz and Ralston 2012), most notably in the spatial organization and other aspects of the oppida, the major settlements of the period. Oppida excavated to a sufficient scale often display many of the characteristics of urbanizing sites, albeit with their individual idiosyncrasies (Fernández-Götz et al. 2014; Fichtl 2005, 2012). While some developed into long-term successful settlement locations, others were rapidly abandoned, sometimes in favour of other, nearby, sites.

There were, however, urban experiences and episodes of early state formation in temperate Europe before the oppida (Collis 2014; Milcent 2014; Verger 2015). Over the last two decades, it has become increasingly evident that the first urban centres in Europe north of the Alps developed between the end of the seventh and the fifth century BC, the most recent cases being at least 300 years earlier than the oppida (Brun and Chaume 2013; Fernández-Götz and Krausse 2013; Krausse 2008a, 2010; Sievers and Schönfelder 2012). These centres, of which the Heuneburg, Mont Lassois, Bourges, Hohenasperg, Ipf, Glauberg and Závist are prime examples, extend from Central France in the west to Bohemia in the east (Fig. 1). Many of them are usually referred to as Fürstensitze ('princely seats'), following the nomenclature popularised by German scholars such as Wolfgang Kimmig from the late 1960s. Given their early date, this series of central places-and characteristic features of the territories associated with them-are essentially an archaeological phenomenon, in contrast to the later oppida, for the evaluation of which Classical historical testimony and ancient toponyms can frequently and usefully be combined with data recovered archaeologically.

The 'classic/standard' model of the Late Hallstatt Fürstensitze-based primarily on the results of the excavations at the Heuneburg-was presented by Kimmig in 1969. He defined them as political and administrative centres comprising a fortified central area on a topographically elevated site, accompanied by finds of objects from the Mediterranean area, and sumptuous burials in the immediate surroundings (Kimmig 1969). Later research has on the one hand confirmed many of these assumptions, but on the other emphasized the diversity and heterogeneity of the sites which have been classified as Fürstensitze. Common to almost all of the excavated examples is the fact that they were settled, intensively at least, for a relatively short period spanning a few generations, perhaps averaging between one and two centuries (Krausse 2008a, 2010). These often heavily-enclosed sites bear testimony to processes of differentiation and hierarchization in the regional settlement pattern that were concurrently an expression of, and a catalyst for, 


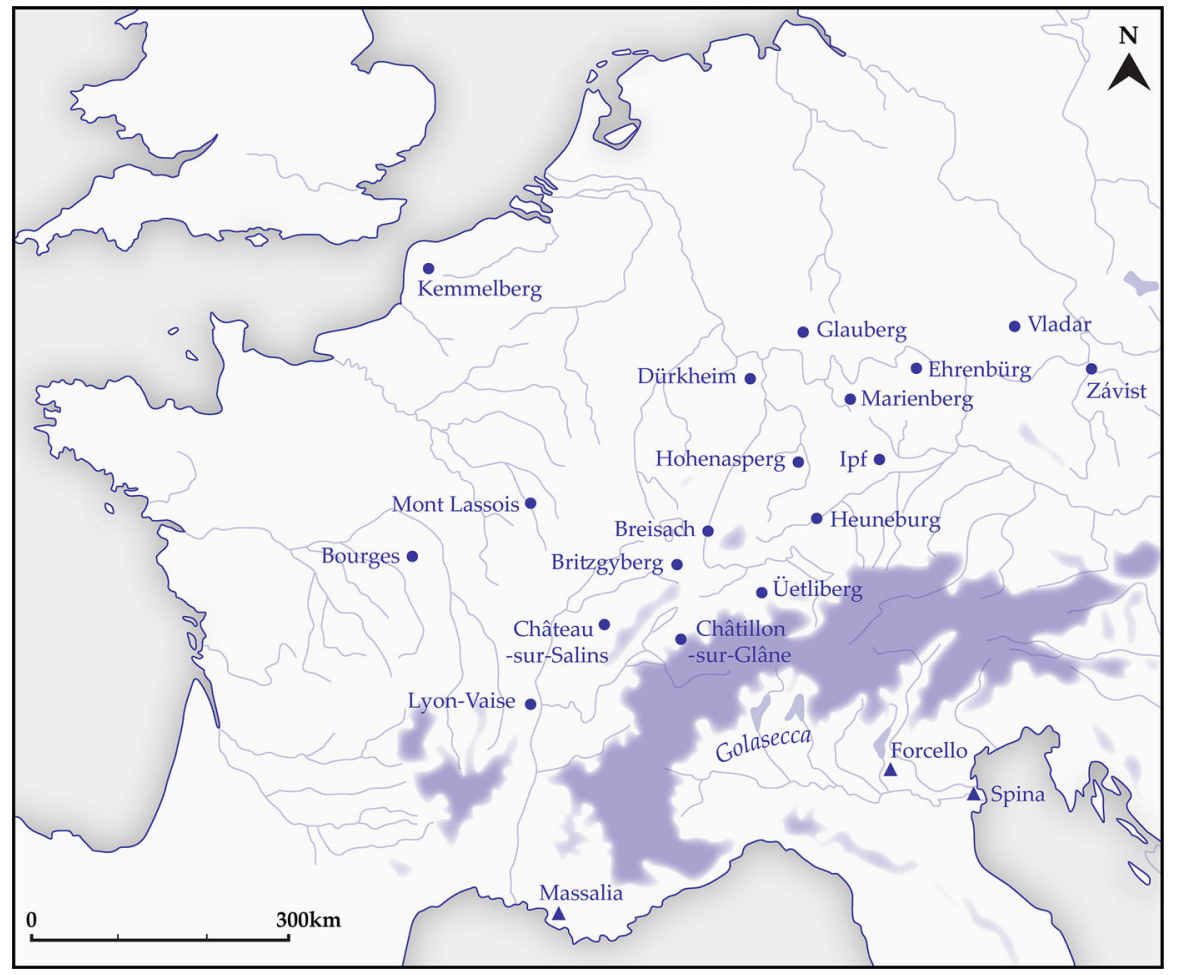

Fig. 1 Fürstensitze north of the Alps and selected sites in Mediterranean Europe (authors)

increasing social inequality, marked by the establishment of aristocratic-in some cases even monarchical-forms of rule, and elites that cultivated close contacts with the Mediterranean world (Fernández-Götz and Krausse 2013; Verger 2015). However, the set of princely seats presents considerable variability in terms of their characteristics, enclosed areas, internal layouts and chronological development: no two are identical. Selected evidence from some of the most important of these settlements, for which recent excavations and geophysical and other surveys have provided significant new archaeological data, is outlined below.

\section{Complexity and Heterogeneity at Selected Early Iron Age Central Places}

\section{The Heuneburg}

Since the beginning of systematic open area excavations there in the early 1950s, the Heuneburg has played a key role in the characterization of Early Iron Age centres of power and the Late Hallstatt societies which occupied them. The discovery of an elaborate Phoenician-, Etruscan- or Greek-inspired mudbrick wall, 
and Mediterranean objects such as high quality Attic pottery from mainland Greece, attracted considerable attention. Detailed recording of the complex site stratigraphy revealed 14 building and 10 fortification phases during Hallstatt D (Fernández-Götz 2014b; Gersbach 1995, 1996). Unlike other sites considered below, the Heuneburg was largely abandoned after the destruction of its Early Iron Age settlement-with the exception of limited use in Medieval times - thus allowing exceptionally good near-surface preservation of the remains (Krausse et al. 2016).

An important Middle Bronze Age occupation here was followed by several centuries of disuse before settlement restarted around 630/620 BC. During this first Iron Age phase, the hilltop or acropolis, which overlooks the upper Danube and extends to some three hectares, was occupied by groups of farmsteads located within palisaded enclosures; the overall layout suggests the transfer of rural settlement units to a more confined area. This compression of the evidence in plan represents a common phenomenon in European Iron Age centralization. A fundamental restructuring of the site occurred around or soon after $600 \mathrm{BC}$, when a traditional earth and timber wall of Kastenbau type was replaced by a nonindigenous wall design consisting of a mudbrick superstructure erected on a prepared limestone foundation. Concurrently, the internal arrangement of the level hilltop was completely modified. All the farmsteads were demolished (there is no sign of destruction by fire), and a regular planned settlement was established, with rows of individual houses set along a network of streets that crossed the interior in a rectilinear arrangement. This radical transformation can only be interpreted as the intended result of a political decision.

But it has become increasingly clear that occupation at the Heuneburg extended considerably beyond the remains on the hilltop plateau. In fact, between the end of the seventh and the middle of the sixth century BC, this acropolis was only the most visible component of a large agglomeration: recent fieldwork demonstrates the existence of an enormous (c. 100 ha) external settlement to the west, north and southwest of this plateau (Kurz 2010). This outer zone was subdivided by an extensive system of banks and ditches, which in turn enclosed dense groups of farmsteads, themselves demarcated by rectangular palisades (Fig. 2). It is tempting to interpret the sub-division of the outer settlement into 'quarters' as evidence for the existence of different kinship groups which coalesced during a process of synoecism that underpinned the creation of the Hallstatt agglomeration.

During this period, the settlement complex is estimated to have had a population of around 5000, thus being perfectly comparable in size to contemporary major Archaic power centres north of the Mediterranean, such as Athens or the Etruscan cities (Fernández-Götz and Krausse 2013). An impressive ashlar gatehouse marked the entrance to the lower town below the acropolis, which was itself protected by a strong enclosure wall enhanced by 17 towers or bastions along its northern and western fronts, probably a reflection of the role of the Heuneburg as the key centre within the territory of a powerful Early Iron Age polity (Fig. 3). The Heuneburg settlement was at this stage also an important centre of production, distribution and innovation, in which skilled craftspeople produced ceramics, brooches, textiles and sapropelite jewellery (Krausse et al. 2016). There are good reasons for believing that particular artefact types that are found widely distributed were actually created at 


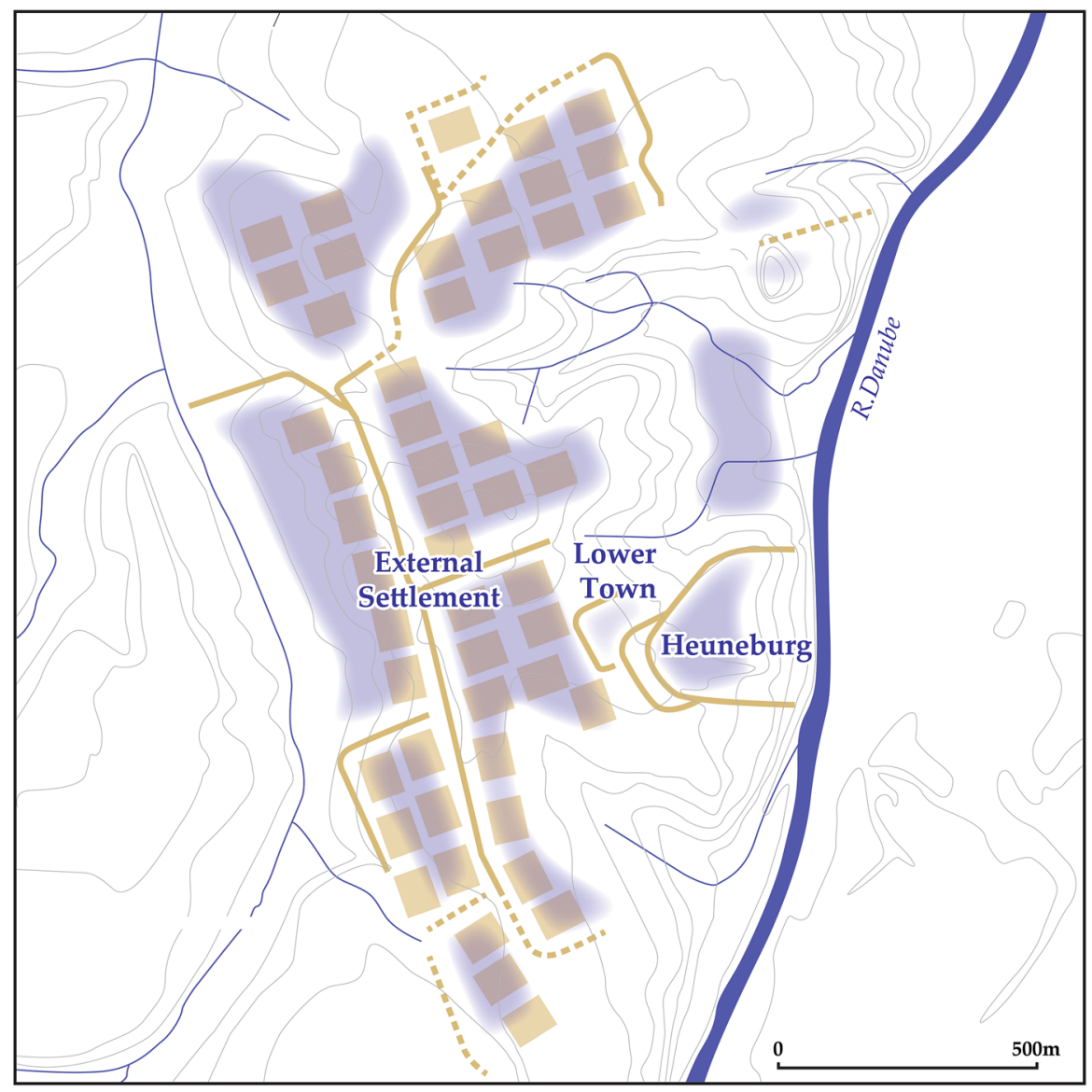

Fig. 2 Plan of the Heuneburg agglomeration during the mudbrick wall phase (authors, based on Kurz 2010)

the Heuneburg; red-and-white coloured vessels with a high neck (Stegmaier 2016) are one example.

This development was interrupted by a major reconfiguration related to a devastating fire which occurred c. 540/530 BC. After this traumatic event, the mudbrick fortification was replaced by a traditional timber-and-earth construction, the internal layout of the acropolis was radically altered and the greater part of the external settlement was never resettled. These major changes suggest that violent conflict followed by significant population decline were the most likely causes. It is unclear whether the former arose through external aggression or a struggle between internal factions. Settlement activity continued on the acropolis and within the lower town for a few generations. On the hilltop, some exceptionally large buildings were probably elite, perhaps even royal, residences and/or assembly halls; interestingly, most of the Mediterranean imports belong to this post-destruction period, and not the time when the settlement was at its most extensive. A further 


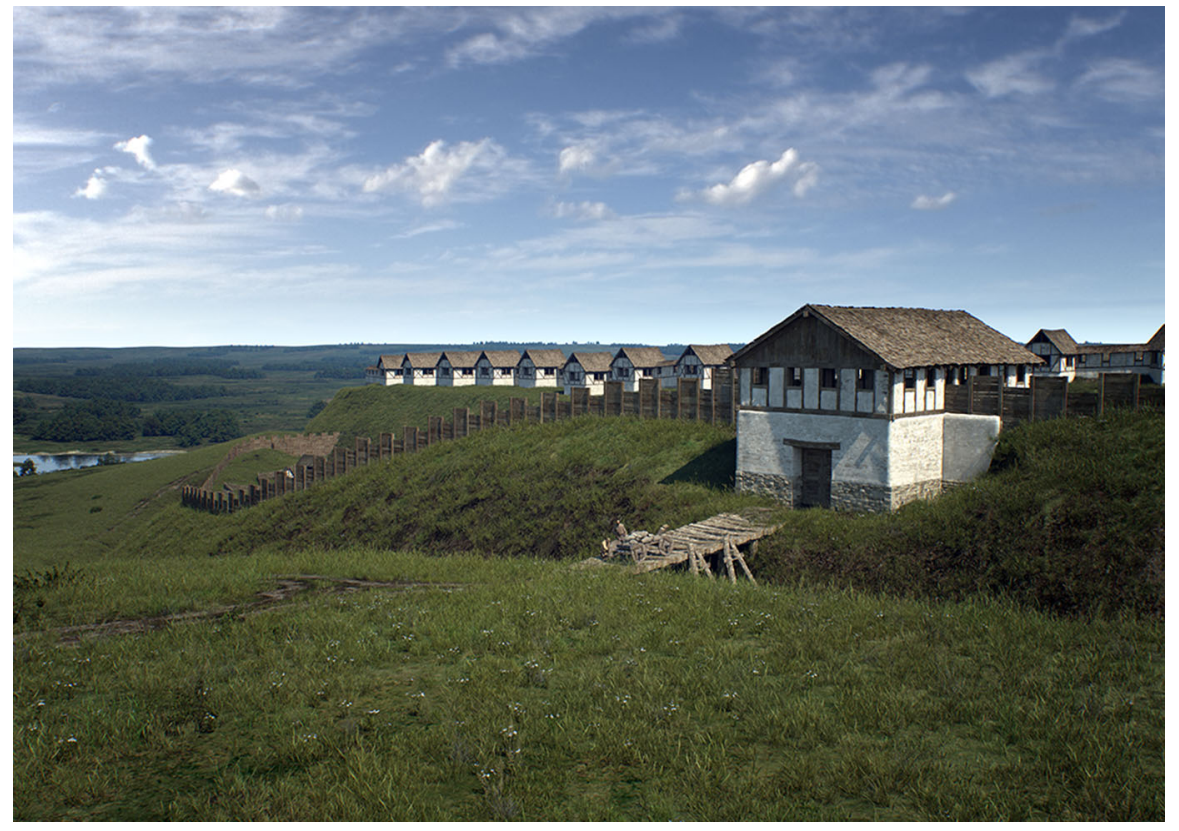

Fig. 3 Entrance gatehouse to the lower town of the Heuneburg, with mudbrick wall and towers of the acropolis in the background (after Krausse et al. 2016; design Faber Courtial; (C) Landesamt für Denkmalpflege im RP Stuttgart)

conflagration finally ended the Iron Age occupation around the middle of the fifth century BC.

\section{Mont Lassois}

The location that is most frequently compared with the Heuneburg is Mont Lassois in Burgundy, France. There are, however, a number of significant differences between these sites, including - to date-the lack of evidence for a large external settlement at Mont Lassois and the detailed chronology of the settlement, which seems mainly to develop between the second half of the sixth and the first half of the fifth century BC. This limestone plateau, which lies beside the upper reaches of the Seine, became famous following the discovery in 1953 of the nearby elite burial at Vix. Here a woman was buried about, or soon after, $500 \mathrm{BC}$ with extremely rich grave goods including a dismantled waggon, rich jewellery, and-most strikinglyan enormous bronze krater produced in one of the western Greek colonies. With a capacity of $1100 \mathrm{~L}$ and a total weight of more than $200 \mathrm{~kg}$, this is the largest metal vessel known from the entire ancient world, reflecting the very high status of the deceased woman (Rolley 2003). The existence of a female dynasty at Mont Lassois, where the three richest nearby burials belonged to women (Vix and two sumptuous graves at Sainte-Colombe-sur-Seine), is suggested (Milcent 2003). On the plain below Mont Lassois and near the tomb of the 'Lady of Vix', the sanctuary of Les 
Herbues was found in the 1990s. From its ditch were recovered fragmentary stone sculptures of a torc-wearing woman and a male warrior. These remains have been interpreted as a heroon, a place of ancestral worship dedicated to the family that ruled from Mont Lassois (Chaume and Reinhard 2007).

The enclosed hilltop settlement itself was until recently poorly understood. Geomagnetic surveys carried out in 2003 over the 5 ha of the summit plateau changed this completely, revealing a settlement layout that was neatly adapted to the local topography (Chaume and Mordant 2011). Its main axis ran north-south and separated complex arrangements of timber buildings that were normally enclosed by ditches, accompanied by pits and sunken features, often cut into bedrock, as well as post-built buildings of differing sizes and forms. The geophysics results indicate that the settlement was planned, organised and complex. Moreover, impressive fortification works surrounded the plateau and ran down the flanks to protect access to the Seine river (Fig. 4).

Within the summit settlement, the most exciting recent discoveries are several large apsidal structures, one of which has been fully excavated (Chaume et al. 2013). At its largest, this building measures $33 \times 20 \mathrm{~m}$ with an unusual semicircular apse forming one end. The scale of this structure, its exceptional

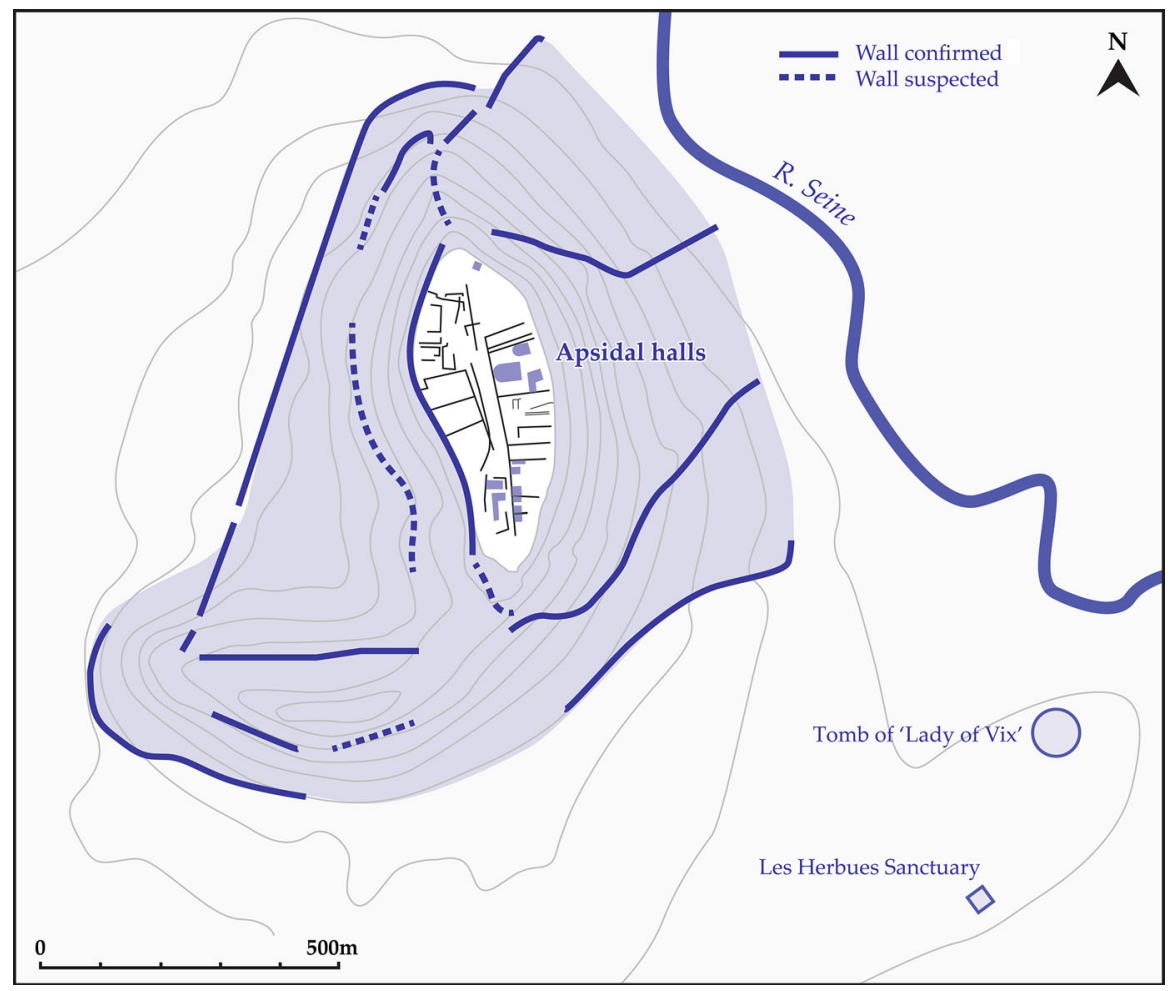

Fig. 4 Mont Lassois: plan of the plateau with associated ramparts and selected external features (after Milcent 2014, modified) 
architecture, elaborate decoration including painted wall plaster, and dominant setting above the river, suggest that its functions were highly prestigious. This is emphasised by the associated finds of fragments of wine amphorae from the Greek colony at Massalia, imported Attic ceramics and impressive quantities of highquality indigenous pottery, suggesting conspicuous consumption at large-scale meetings or celebrations held within it. Both these large apsidal buildings and the monumental buildings at the Heuneburg can be matched amongst the palace structures of the ancient world (Verger and Osanna 2010).

\section{Glauberg}

The heterogeneity of the group of fifth century BC centres of power is further exemplified by the Glauberg. This prominent example of a Fürstensitz is located on the edge of the German Wetterau uplands, north of and rather peripheral to the main distribution of these sites. The Glauberg plateau, c. 8 ha in extent, was enclosed by a massive defensive circuit erected c. 500 BC. Finds from the plateau are relatively modest: they include high-quality pottery finished on the slow wheel (also known at other sites of this series) and metal objects, but both are rare; imports from the

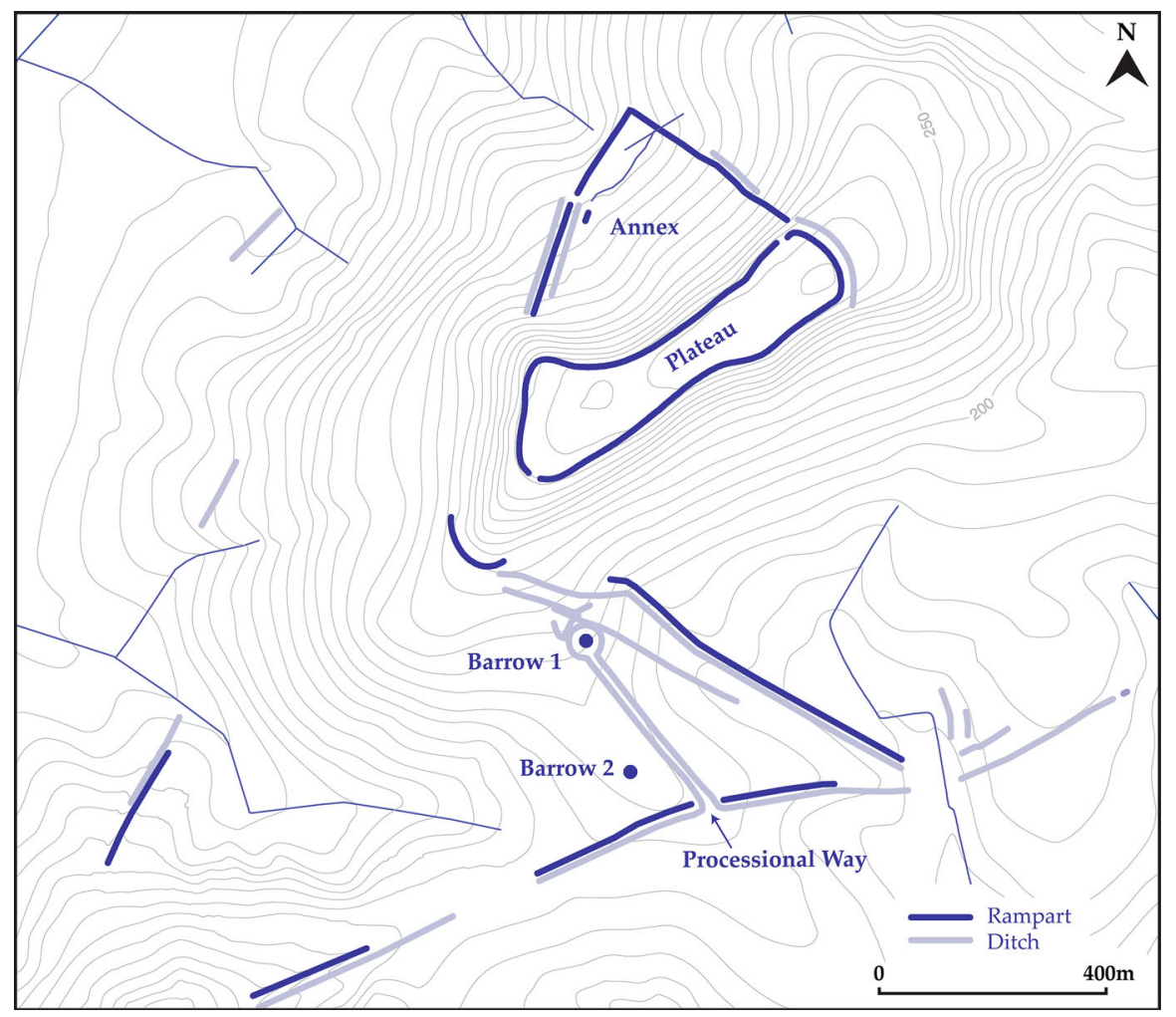

Fig. 5 Glauberg plateau with external bank-and-ditch system, principal barrows and processional way (after Baitinger et al. 2012, modified) 
Mediterranean are completely absent (Baitinger 2010; Hansen and Pare 2016). What marks the Glauberg out is its sumptuous burials and the monumental ditch-and-bank systems known from the slopes below it (Baitinger et al. 2012) (Fig. 5).

The finds from Grave 1 in the barrow placed within a long, ditched avenue are particularly outstanding. The grave goods accompanying the deceased include a golden torc and rings, an iron sword, an elaborately decorated spouted flagon and elements of the metal frame for a 'leaf-crown', an item of clear sacral significance. Moreover, the damaged remains of four anthropomorphic stone statues were discovered lying in the immediate vicinity of this tumulus. One, almost fully preserved, displays attributes that have stunning similarities to the key items in the sumptuous grave just described. It probably represents a member of the local elite transformed into a heroized ancestor (Baitinger and Pinsker 2002).

The Glauberg is thus an impressive example of just how important a role funerary monuments, normally located below the nearby settlement on its hill, played in the development of the main central places in temperate Europe at this time. The central tumulus, together with the stone statues recovered cast down around it, was set axially within a sanctuary attributable to the ancestors that was approached by a ditched processional avenue $350 \mathrm{~m}$ long and $10 \mathrm{~m}$ wide. This was in turn incorporated within an enormous system of banks and ditches that dominated and sub-divided the landscape around the Glauberg itself. Given the very incomplete outer works at the Glauberg, its overall extent is unclear but may have attained 175 ha. Within this large space, the sanctuary was probably conceived as providing a religious focus for the communal identity of various clans and lineages. Leaders and representatives of different family, village and regional groups for whom the Glauberg represented the communal tribal centre, probably came together here to bury key members of their society; and on particular dates for seasonal festivals (Herrmann 2005).

\section{Bourges}

Bourges (later Avaricum of the Bituriges cubi in Caesar's Gallic war, Book VII) lies south of the Loire bend in Berry (central France). Its core occupies a low limestone promontory between tributaries of the river Cher, a main affluent of the Loire. The character of its Iron Age archaeological record is determined by the city's long-term success, such that in the centre deposits are deeply buried at the base of a long urban sequence, but on its margins occur superficially if intermittently in either wetland valley contexts or in formerly agricultural land. Inevitably, more is recoverable archaeologically on the periphery than in its centre. No coherent Early Iron Age defensive system is known; key components are likely to have barred the easiest, southeast, access to the promontory and been eliminated in engineering the Late Iron Age successor. Evidence of Hallstatt settlement, industry (Augier et al. 2009) and funerary practices has accumulated since the mid 19th century (Milcent 2004), much enhanced by modern rescue excavation (Fig. 6).

Small sondages at the apex of the promontory have revealed settlement evidence comprising fragments of major buildings, mudbricks, and painted plaster accompanied by Attic pottery, local wheel-finished wares and indications of a diet rich in game. An elite milieu is indicated at Littré, with localized stratification intimating 


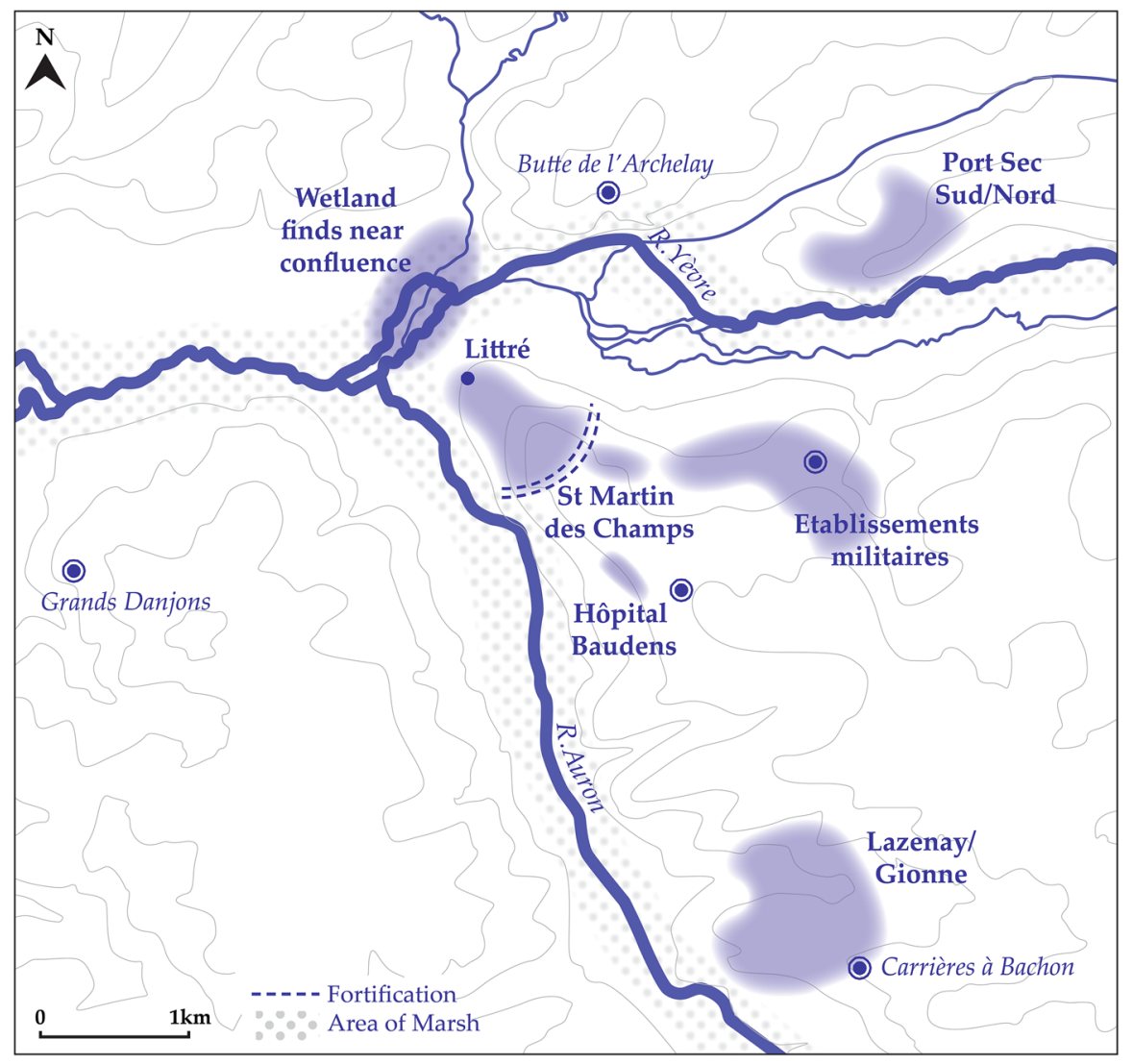

Fig. 6 Plan of Bourges and surroundings in the fifth century BC (after Milcent 2014, modified)

successively a HaD1/D2 (with black-figure) and D3 (with red-figure) horizon. Elements of this were confirmed in excavation at the Hôtel-Dieu (Augier et al. 2007). South and thus outwith the postulated defences, some two kilometres away, sub-rectangular features interpreted as workshops were encountered at SaintMartin-des-Champs (Milcent 2007) and elsewhere (e.g. Hôpital Baudens). This craft area, claimed to demonstrate a regular layout, provided evidence for e.g. lignite bracelet manufacture and ironsmithing in contexts which also furnished imports indicating wine consumption (Attic red-figure; Massaliote amphorae), a pattern which varies considerably from the 'top down' models of elite consumption and redistribution that normally prevail. Similar workshops, also intimating copperalloy jewellery-making, horn-working and weaving, as well as iron-working (Filippini 2015) were found interspersed with other features at Port-Sec, over an extensive area (c. 11 ha excavated) $3 \mathrm{~km}$ east of the core across the marshy Yèvre river valley (Augier et al. 2012; Ralston 2007). An admixture of functions is indicated from examination of the Établissements militaires during 19th century development and again recently: burials (including secondarily within storage pits), 
a substantial ditch, and further indications of craft-working. Barrows and other burials (e.g. route de Dun) from the immediate vicinity and the broader hinterland produce copper-alloy imports and limited evidence for vehicles from Les Grands Danjons and notably including a burnt waggon body at Les Carrières de Bachon, Lazenay (Milcent 2004). After Late Bronze Age and Hallstatt C antecedents (including long swords of the latter period) from wetland and burials in the vicinity, the high point of Bourges in occupation terms, when it may have extended to $\mathrm{c}$. 200 ha, seems to be represented by Hallstatt D3/La Tène A1. The evidence from Port Sec Sud strongly suggests wholesale abandonment, with the systematic backfilling of features, at the end of this phase. Although not wholly deserted, Bourges declined very rapidly thereafter, with only vestigial evidence for a continuing use of the site until its subsequent, Later Iron Age, resurgence.

\section{Lyon}

Lyon-Vaise, the 9th arrondissement in the northwest of the modern city of Lyon (Rhône), is a mostly low-lying sector of the conurbation placed west of the river Saône and north of the Saône-Rhône confluence. Traces of an Early Iron Age antecedent to Roman Lugdunum, founded in 43 BC, initially came to light archaeologically in the mid 1980s during rescue excavations associated with the construction of a new subway and have multiplied as a result of subsequent development-led rescue work. Some thirty excavations now indicate the existence of a seemingly unenclosed settlement and artisanal zone here extending to at least 55 ha, and perhaps even thrice that; there is also restricted evidence for contemporary settlement at the foot of the Croix-Rousse upland on the opposite bank of the river (Fig. 7).

While a few earlier (Hallstatt C2 onwards) inhumations are known, settlement evidence, including storage pits and four-post buildings interpreted as granaries from Vaise, spans from the end of the sixth century BC until nearly the end of the succeeding century-from late in Hallstatt D2 through to La Tène A1. The structural evidence from Vaise indicates post-built and sleeper-beam domestic structures (some with traits shared with Alpine areas to the east), storage activities, and (less commonly) fenced enclosures for livestock. Imports include fragments of c. 140 Massaliote wine amphorae, Rhodian glass perfume bottles, and other Greek and Etruscan items; imported pottery, recovered from 23 of the 30 sites tested, is widespread. There is also abundant evidence for craft activities including iron- and bronze-working (especially in the rue des Tuileries: Filippini 2015); textile production (spindle-whorls and loom weights); and the working of animal horn. In total, almost four hectares have been excavated, with some sites indicating a separation between craft and living areas, and intermittent fencing and ditching indicating sub-division of the area (Carrara et al. 2009, p. 231).

Stray finds (Perrin and Bellon 1997) recovered in earlier times from the Plateau de Loyasse, which overlooks the Vaise area from the south and dominates the sector between the Saône and the Vallon de Trion, intimate that the accompanying acropolis may have been located here. For Lyon-Vaise it has been suggested that Massaliote merchants were attracted to a pre-existing indigenous industrial agglomeration as a port-of-trade (Carrara and Maza 2009, p. 9; Carrara et al. 


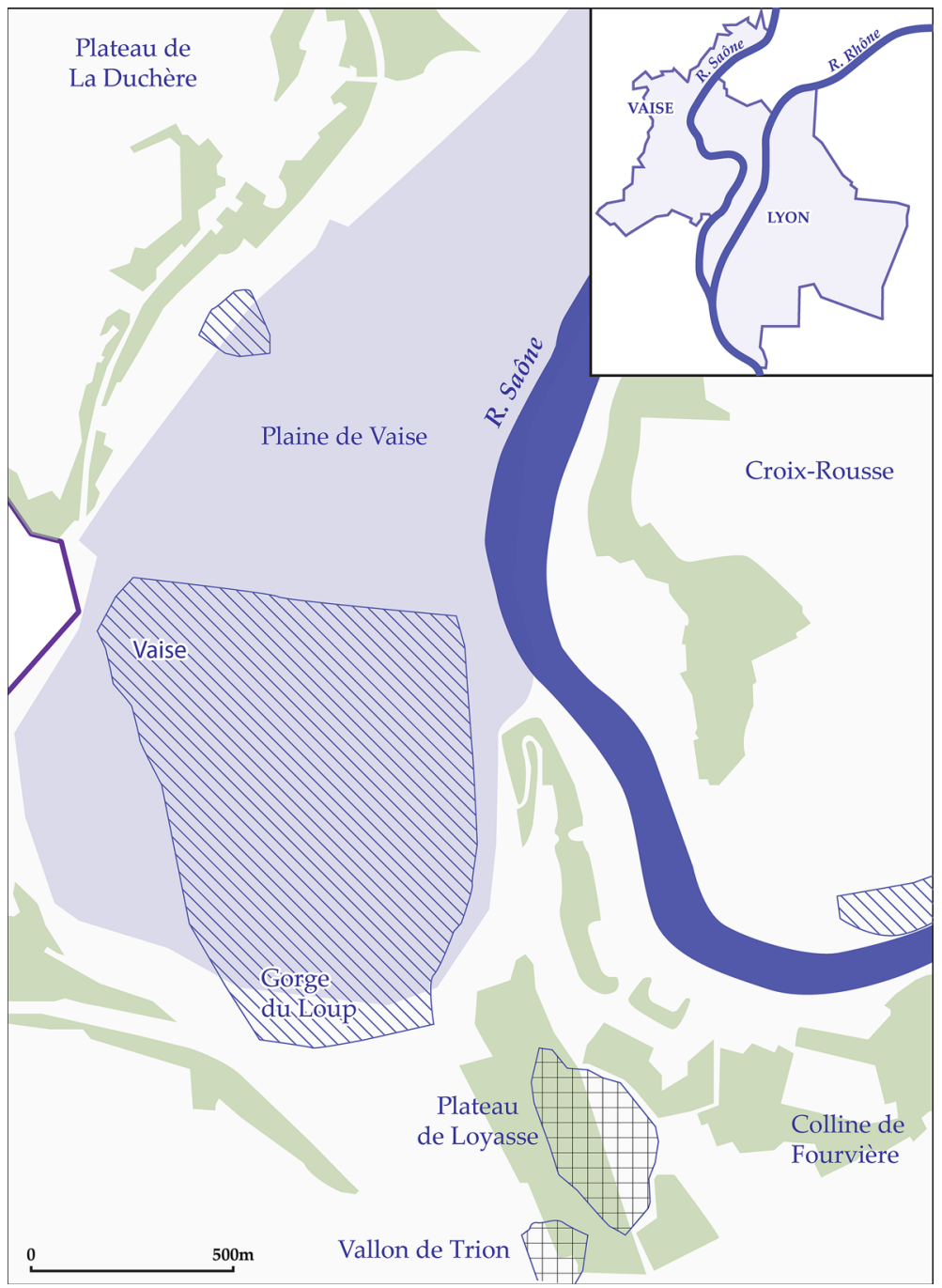

Fig. 7 Lyon: Plan with the extent of the Lyon-Vaise settlement of the sixth-fifth centuries BC and the suspected acropolis site (after Carrara et al. 2009)

2009). Little is known of its seemingly rapid abandonment, but the fourth and third centuries $\mathrm{BC}$ are unrepresented here.

\section{An Ephemeral Urban Phenomenon}

The social, economic and political complexity of the archaeological evidence recovered to date from the sites described above is manifest. Several further cases could be added on the basis either of the evidence recovered from the settlement 
itself or from the rich burials examined in their vicinities. Amongst these would be Hohenasperg, Ipf bei Bopfingen, the Münsterberg at Breisach, Ehrenbürg bei Forchheim, and Vladař (see overview in Krausse 2008a, 2010; Krausse et al. 2016, pp. 157-190). Given the new results, it seems appropriate to apply the term 'urban' to at least some of these centres of power, such as the Heuneburg during the mudbrick wall period, or Bourges. These two major settlements seem to fit the notion of 'low density urbanism' as developed by Roland Fletcher (2012), and thus differ from the high density urbanism postulated in Gordon Childe's classic model (Childe 1950). In fact, at other times and places, there have been urban sites around the world characterized by their large areas and variety of functions combined with low-density occupation estimated at fewer than fifty people per hectare. Angkor, Cahokia and Great Zimbabwe are famous examples, but some Early Iron Age Fürstensitze, at least outwith their acropoleis, and also some Late Iron Age oppida (see Moore 2017, this special issue), should be added to the list.

The importance within some Fürstensitze of skilled artisanal activity on a significant scale, as well as of mercantile functions, is reflected not only by the presence of workshops for specialised craftspeople-or even entire sectors given over to them, as on the margins of Bourges - but by imported goods, which are not recovered exclusively from elite contexts. But there was plainly considerable variation amongst these sites: we need to acknowledge that, on the archaeological evidence available to date, there were other places within the Fürstensitz series, for example the Glauberg, that seem primarily to have been locations for assemblies, cult sites or places of refuge, rather than centres that might qualify as urban. Therefore, we can maintain that whilst they were all complex central places, only some of them can be classified as 'cities' from a comparative urban perspective (cf. Smith 2014, 2016). In this article, we follow the context-dependent definition of 'city' proposed by Fernández-Götz and Krausse (2013, p. 480): 'A numerically significant aggregation of people permanently living together in a settlement which fulfils central place functions for a wider territory'. 'Central place', in turn, can be defined as 'any kind of place with central functions for a supra-local community' (Gerritsen and Roymans 2006, p. 255).

$\mathrm{Be}$ that as it may, there is a great deal of evidence suggesting that during the Hallstatt D and earlier La Tène A periods, and so from the late seventh to the late fifth century BC, numerous local and regional groups in a swathe of temperate Europe north of the Alps were integrated into larger collective entities. With regard to the 'social typologies' that have been defined by authors such as Johnson and Earle (2000), the communities which were established around centres of power such as the Heuneburg, Hohenasperg, Mont Lassois or Bourges can best be placed as transitional between complex chiefdoms and early states. These were hierarchicallyorganized societies, manifested archaeologically by large, normally fortified settlements surrounded by an immediate hinterland of elaborate barrow burials which served as a last resting place for members of the socio-political elite and their relatives or immediate retinues, and which included internal wooden chambers and rich grave-goods (e.g. Hohmichele, Gießübel-Talhau, Hochdorf, Grafenbühl, Kleinaspergle, Sainte-Colombe, and Vix; see Krausse 2006 for a summary). Some of the richest burials of the period belong to women, so that their prominent social 
role_-including positions of political and religious leadership_-needs to be stressed (Metzner-Nebelsick 2009; Milcent 2003). The recently excavated grave of Bettelbühl across the Danube near the Heuneburg-dendrochronologically dated to the very beginning of the sixth century $\mathrm{BC}$ - is among the earliest examples of these sumptuous female graves (Krausse et al. 2017). Numbers of these graves were robbed relatively close to their time of construction; alongside the evidence for destruction by fire, notably at the Heuneburg, this suggests that the status of these socio-political elites was far from uncontested.

Despite the heterogeneity of the sites classified as Fürstensitze, it is possible that most of them represented focal settings for tribal polities, and these polities might have maintained relations of the types proposed in the peer polity interaction model. This may also be indicated by their nearly regular spatial distribution, which suggests that they are at the top of settlement hierarchies: they are relatively accessible to each other, being of the order of two to five days' walk (or less on horseback) from their nearest neighbours (Brun 1988; Nakoinz 2013). The high degree of connectivity amongst them is reflected in the appearance of similar if not identical items of material culture-for example certain fibulae types-across numbers of these sites. The concentration of sumptuous elite burials in the environs of these centres can be regarded as further testimony to their political and administrative functions. The Fürstensitze, or at least many of them, could have acted as territorial foci for Early Iron Age tribal entities. In the case of the Hohenasperg hill, for example, Verger (2006, p. 38) suggests it should not be considered a princely residence but rather the main seat of the tribe, the location for particular assemblies and collective ceremonies which were to be held at a neutral location, external to the estates of the major aristocratic families who controlled the plains below it.

The rise of these centres can be regarded as the crystallization of the first urbanization processes north of the Alps, similar to those observed in other regions across Eurasia (see contributions in this special issue; also Fernández-Götz and Krausse 2016). However, and in contrast to the centralization processes observed in many areas of the Mediterranean Basin, their development in temperate Europe was a short-lived phenomenon (Ralston 2010) which differed in date and duration from site to site. Where excavation has been taken furthest, it is clear that within the overall duration of this class of site, most seem to have been at their most extensive and powerful for a rather briefer span. The Heuneburg was finally abandoned around the middle of the fifth century BC, more or less contemporaneously with comparable settlements such as Mont Lassois. At around this time, a number of other central places became more significant, for example Bad Dürkheim and Glauberg. The zenith of these centres of power occurred somewhat later. Located generally further north within temperate Europe, and on the margins of the earlier distribution of key sites, they were able to maintain their significance for a further generation or two, in other words until the end of the fifth century BC. But they too were abandoned no later than the early fourth century BC.

In general terms, this short-lived wave of centralization and urbanization was followed by a phase where decentralization characterized the settlement record (Buchsenschutz et al. 2012), which can be interpreted as a prime example of the 
non-linear character of history (Fernández-Götz 2014a; Krausse 2008b). These temperate European sites and their hinterlands can thus be envisaged as rather shortlived, unstable, ephemeral polities. They nonetheless represent a significant stage in the cultural and political development of later prehistoric temperate Europe, albeit one which was not immediately consolidated, but which rather gave way to subsequent collapse and was in some cases not far removed in time from the displacement of large groups of population in the course of the so-called 'Celtic' migrations of the fourth century BC.

\section{Concluding Remarks: Challenging Traditional Views}

Three points appear particularly important from a 'pathway to power' perspective.

\section{Tracing the Hallstatt $\mathrm{C}$ Roots}

In standard explanations of the emergence of these Early Iron Age settlements, scholars such as Kimmig have interpreted the processes of centralization and hierarchization apparent in the Fürstensitze and the rich elite burials (Fürstengräber) of the Hallstatt D period primarily as a response to increasing contacts with the Mediterranean world and in particular as a reaction to (or even a result of) the foundation of the Greek colony of Massalia in Mediterranean France around 600 BC (e.g. Kimmig 1983). However, rich and impressive Hallstatt $\mathrm{C}$ burials, such as Gomadingen or Frankfurt-Stadtwald in Germany, or others that include wheeled vehicles amongst their accoutrements, clearly show that increasing social inequalities and the development of powerful local elites had begun several decades before the arrival of the first Greek colonists in southern France; that there is also considerable continuity between Hallstatt C and D status markers (Schumann 2015) in temperate Europe suggests that Mediterranean influences, when present, were less significant drivers of change in temperate Europe than is sometimes envisaged. Therefore the processes underlying the increased complexity and stratification apparent in the Fürsten phenomena discussed above should be considered primarily indigenous, with deeper roots in the Earliest Iron Age and even latest Bronze Age of the west-central temperate European heartland. In the case of the Heuneburg, the first settlement phase, Period IVc, started around $630 \mathrm{BC}$, at the very beginning of Hallstatt D1; it is very likely that the enormous external settlement was also in existence during this earliest Iron Age settlement phase. The process of synoecism that lay at the start of the development of the agglomeration thus clearly pre-dates by at least one generation the initial foundation of Massalia, and, still more, the resultant Mediterranean penetration into the heartland of the continent. Moreover, again taking the case of the Heuneburg, and leaving aside the exceptional architecture of its mudbrick wall, evidence-in the form of actual imported goodsfor Mediterranean contact and influence at the settlement itself is minimal until the restructuring that took place after the major destructive fire around 540/530 BC. The variability in the kinds of archaeological evidence recovered across the modern agglomeration of Bourges, and its chronological patterning, also strongly indicate 
that an uncritical application of Wallerstein's world systems theory (1974)—in which both push and pull factors from the supposedly stronger cultures to the south are seen entirely to dominate local circumstances-is not readily applicable to the recovered evidence. Trade and exchange with the Mediterranean was likely not the prime mover in the cultural changes apparent in the Fürstensitze, but such changes were rather more a consequence of demographic growth and increasing internal inequalities which had their roots in Hallstatt C. The key role of demographic growth in the development of more centralized forms of power has been stressed since the seminal work of Robert Carneiro (1967) on early state formation. Such issues are not simply about total populations in particular regions in relation to carrying capacities, although these may be relevant, but more particularly about the associated increases in 'social density', that is, the frequency of communication and interaction occurring between individuals and groups through their social, political and economic networks (cf. Ortman et al. 2014). Moreover, Christopher Gosden has already demonstrated in his critique of Frankenstein and Rowlands' (1978) prestige goods model that in predominantly agrarian societies such as those of the Hallstatt period, power and status would have depended mainly on land ownership and the control of local production (Gosden 1985; see also Karl 2015), as indeed they continued to do in the succeeding centuries (Buchsenschutz et al. 2012), Therefore, the appearance of Mediterranean imports in graves and settlements should be regarded in the main as a product rather than the cause of endogenous sociopolitical processes that were in reality already under way.

\section{Towards a Biography of Sites}

Recent fieldwork has shown that the extensive, 100 ha, agglomeration of the Heuneburg existed solely during Hallstatt D1, for about three generations, whereas Mont Lassois seems to have enjoyed its zenith during the two generations of the Hallstatt D3 phase. By the time the rich male burial at Hochdorf near the Hohenasperg took place, the outer settlement of the Heuneburg had already been destroyed and the scale of the Heuneburg complex had been significantly reduced. Bourges, for its part, had its greatest period of expansion during Hallstatt D3 and the beginnings of La Tène A (Fig. 8). From this small selection of examples, we can already testify to the diverse life histories of individual sites, whose particular trajectories as nodal places in networks need increasingly to be taken into account. Moreover, a number of these Early Iron Age centres occupy locations which had already been inhabited or at least frequented during the developed stages of the Bronze Age, in some cases with evidence for their sacred significance at this earlier time such as at Závist (Drda and Rybová 2008) and Mont Lassois (Chaume et al. 2011). We might even consider that the earlier significance of certain places could have been a reason for the locational choices made at the time of the foundation of certain Fürstensitze; the placing of settlements often builds on layers of memory and myth. 


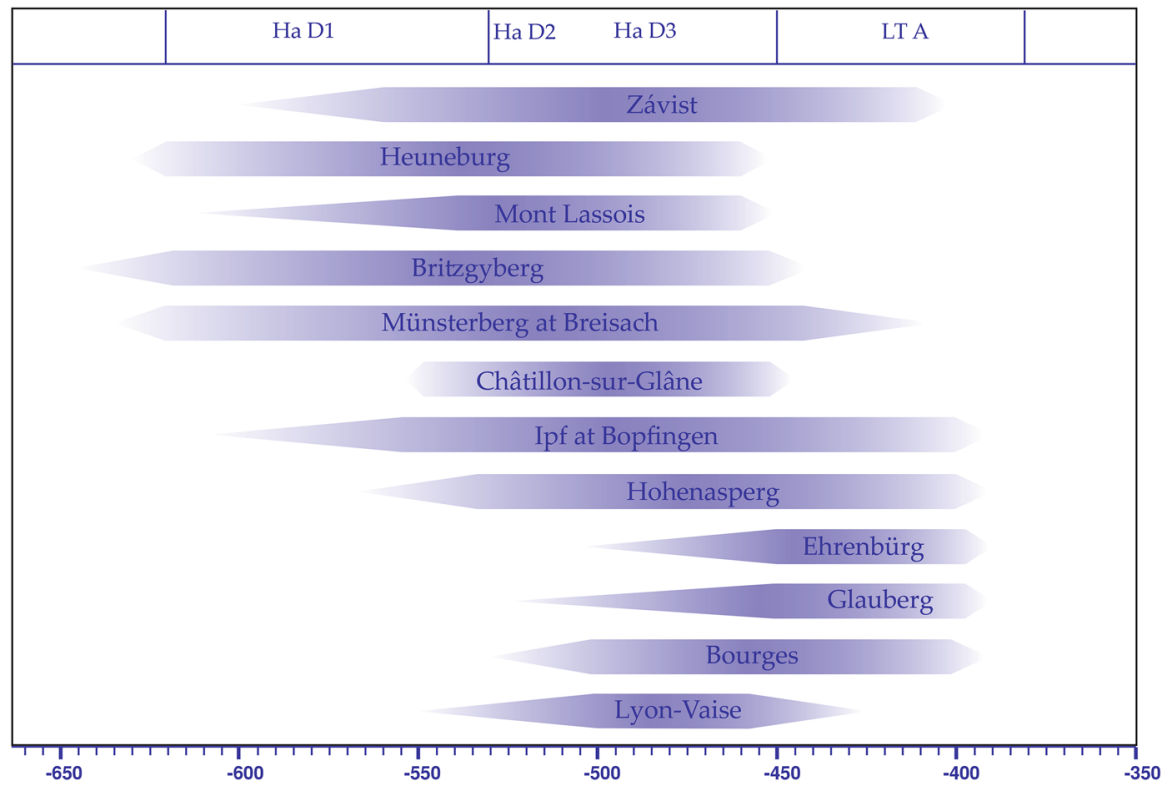

Fig. 8 Indicative lifespans of selected Fürstensitze sites (authors)

\section{An Eventful History}

At least partly linked to the previous point is the need to take into account the existence of changing constellations of power and the impacts that short-term events - sometimes directly or indirectly linked to broader trends-could have had on the trajectories of specific communities (Bolender 2010). One example is the possibility of episodes of intertribal warfare; in fact, an external attack is the most likely explanation for the destruction of the Heuneburg both at the end of the mudbrick wall phase (the Period IV-III transition) and towards the middle of the fifth century BC (end of Period I). The conscious destruction of representational sculptures of ancestral individuals such as those of Vix-Les Herbues and the mutilated and overthrown stone sculptures below the Glauberg can be interpreted as the result of violent conflict, although in these cases tensions could have arisen from within societies, e.g. as local uprisings against the elites (Demoule 1999). Along with evidence for the robbing of elite graves not long after burials took place, such conflict indicates that the position of the elites was not uncontested. A different scenario can be proposed for the apparently planned abandonment of the external craft sector of Port Sec Bourges towards the end of the fifth century BC. An echo of this may be recorded in The early history of Rome (Livy V, 34), in the mass migration of the Bituriges and other tribes from central and eastern France to Italy apparently as a result of a political decision. This is yet another suite of evidence which suggests that the phenomena represented by the political and social arrangements encapsulated in the Fürstensitze and Fürstengräber were both fragile and ephemeral. Such circumstances lead us to concur with Kristiansen's (1998, 
p. 417) view that 'we have to give up the modernist liberal myth that change and progress was always accomplished peacefully and freely, and that conflict, disruption and migration did not occur in Prehistory'. Iron Age archaeology has made great advances by focusing on long-term socio-economic developments; it is now time to reincorporate the temporality of short-term political events as a complementary factor into the debate.

Open Access This article is distributed under the terms of the Creative Commons Attribution 4.0 International License (http://creativecommons.org/licenses/by/4.0/), which permits unrestricted use, distribution, and reproduction in any medium, provided you give appropriate credit to the original author(s) and the source, provide a link to the Creative Commons license, and indicate if changes were made.

\section{References}

Augier, L., Baron, A., Filippini, A., Milcent, P.-Y., Pescher, B., \& Salin, M. (2009). Les activités artisanales de la fin du $\mathrm{VI}^{\mathrm{e}}$ et du $\mathrm{V}^{\mathrm{e}}$ s. av. J.-C. attestées aur le site de Bourges (Cher). In O. Buchsenschutz, M.-B. Chardenoux, S. Krausz, \& M. Vaginay (Eds.), L'âge du Fer dans le boucle de la Loire/Les gaulois sont dans la ville. Actes XXXII Coll Assoc fr Ét Âge Fer, = 35 Suppl Rev Arch Centre Fr (pp. 39-66). Tours: Bituriga.

Augier, L., Buchsenschutz, O., Durand, R., Filippini, A., Germinet, D., Levéry, M., et al. (2012). Un complexe princier de l'âge du Fer: Le quartier artisanal de Port Sec sud à Bourges (Cher). Bourges: Bituriga.

Augier, L., Buchsenschutz, O., \& Ralston, I. (Eds.). (2007). Un complexe princier de l'âge du Fer: L'habitat du promontoire de Bourges (Cher) (VI $-I V^{e}$ s. av. J.-C.). Bourges: Bituriga.

Baitinger, H. (2010). Der Glauberg: Ein Fürstensitz der Späthallstatt-/Frühlatènezeit in Hessen. Materialien zur Vor- und Frühgeschichte von Hessen, 26. Wiesbaden: Landesamt für Denkmalpflege Hessen.

Baitinger, H., Hansen, L., \& Pare, C. (2012). Ein Zentrum an der Peripherie? Der Fürstensitz auf dem Glauberg. Die Welt der Kelten: Zentren der Macht-Kostbarkeiten der Kunst (pp. 157-164). Ostfildern: Jan Thorbecke Verlag.

Baitinger, H., \& Pinsker, B. (Eds.). (2002). Das Rätsel der Kelten vom Glauberg: Glaube-MythosWirklichkeit. Stuttgart: Konrad Theiss.

Bolender, D. (Ed.). (2010). Eventful archaeologies: New approaches to social transformation in the archaeological record. Buffalo: State University of New York Press.

Brun, P. (1988). Les résidences princières comme centres territoriaux: Éléments de vérification. Les princes celtes et la Méditerranée (pp. 124-143). Paris: La Documentation Française.

Brun, P., \& Chaume, B. (2013). Une éphémère tentative d'urbanisation en Europe centre-occidentale durant les $\mathrm{VI}^{\mathrm{e}}$ et $\mathrm{V}^{\mathrm{e}}$ siècles av. J.C.? Bulletin de la Société Préhistorique Française, 110(2), 319-349.

Buchsenschutz, O., Gruel, K., \& Lejars, T. (2012). L'Âge d'or de l'aristocratie celtique, IV ${ }^{\mathrm{e}}$ et III ${ }^{\mathrm{e}}$ siècles avant J.-C. Annales, Histoire, Sciences Sociales, 67, 295-324.

Buchsenschutz, O., \& Ralston, I. (2012). Urbanisation et aristocratie celtiques. In S. Sievers \& M. Schönfelder (Eds.), Die Frage der Protourbanisation in der Eisenzeit. La question de la protourbanisation à l'âge du Fer (pp. 347-364). Bonn: Habelt.

Carneiro, R. L. (1967). On the relationship between size of population and complexity of social organization. Southwestern Journal of Anthropology, 23, 234-243.

Carrara, S., \& Maza, G. (2009). Les antécédents de la colonie, du VI ${ }^{\mathrm{e}}$ au I ${ }^{\mathrm{er}}$ s. av. J.-C. In M. Poux (Ed.), Lyon: Capitale de la Gaule romaine. L’Archéo-Théma, 1, 6-11.

Carrara, S., Maza, G., \& Rottier, S. (2009). L'agglomération urbaine de Lyon-Vaise, Rhône à la fin du $\mathrm{VI}^{\mathrm{e}}$ et au $\mathrm{V}^{\mathrm{e}}$ s. av. J.-C.: Bilan des découvertes. In O. Buchsenschutz, M.-B. Chardenoux, S. Krausz \& M. Vaginay (Eds.), L'âge du Fer dans le boucle de la Loire/Les gaulois sont dans la ville. Actes XXXII Coll Assoc fr Ét Âge Fer, = 35 Suppl Rev Arch Centre Fr (pp. 207-235). Tours/Bourges: Bituriga. 
Chaume, B., \& Mordant, C. (Eds.). (2011). Le complexe aristocratique de Vix: Nouvelles recherches sur l'habitat, le système de fortification et l'environnement du mont Lassois. Dijon: PU Dijon.

Chaume, B., Nieszery, N., \& Reinhard, W. (2013). L'enclos des grands bâtiments absidiaux du plateau du mont Saint-Marcel. Bulletin archéologique et historique du Châtillonnais, 47(4), 13-19.

Chaume, B., Nieszery, N., Reinhard, W., \& Ballmer, A. (2011). Un dépôt céramique du Bronze final IIIb (Fait 11). In B. Chaume \& C. Mordant (Eds.), Le complexe aristocratique de Vix: Nouvelles recherches sur l'habitat, le système de fortification et l'environnement du mont Lassois (pp. 487-502). Dijon: PU Dijon.

Chaume, B., \& Reinhard, W. (2007). Les dépôts de l'enclos cultuel hallstattien de Vix « les Herbues » et la question des enceintes quadrangulaires. Bulletin de la Société Préhistorique Française, 104(2), 343-367.

Childe, V. G. (1950). The urban revolution. Town Planning Review, 21, 3-17.

Collis, J. (2014). Urbanisation in temperate Europe in the Iron Age: Mediterranean influence or indigenous? In M. Fernández-Götz, H. Wendling, \& K. Winger (Eds.), Paths to complexity: Centralisation and urbanisation in Iron Age Europe (pp. 15-23). Oxford: Oxbow Books.

Demoule, J.-P. (1999). La société contre les princes. In P. Ruby (Ed.), Les princes de la protohistoire et l'émergence de l'État (pp. 125-134.). Naples/Rome: Centre Jean Bérard/École française de Rome.

Drda, P., \& Rybová. A. (2008). Akropole na hradišti Závist v 6.-4. stol. př. Kr. Prague: Památky archeologické.

Fernández-Götz, M. (2014a). Identity and power: The transformation of Iron Age societies in northeast Gaul. Amsterdam Archaeological Studies 21. Amsterdam: Amsterdam University Press.

Fernández-Götz, M. (2014b). Understanding the Heuneburg: A biographical approach. In M. FernándezGötz, H. Wendling, \& K. Winger (Eds.), Paths to complexity: Centralisation and urbanisation in Iron Age Europe (pp. 24-34). Oxford: Oxbow Books.

Fernández-Götz, M., \& Krausse, D. (2013). Rethinking Early Iron Age urbanisation in Central Europe: The Heuneburg site and its archaeological environment. Antiquity, 87(336), 473-487.

Fernández-Götz, M., \& Krausse, D. (Eds.). (2016). Eurasia at the dawn of history: Urbanization and social change. New York: Cambridge University Press.

Fernández-Götz, M., Wendling, H., \& Winger, K. (Eds.). (2014). Paths to complexity: Centralisation and urbanisation in Iron Age Europe. Oxford: Oxbow Books.

Fichtl, S. (2005). La ville celtique: Les Oppida de 150 av. J.-C. à 15 ap. J.-C. Paris: Errance.

Fichtl, S. (2012). Les premières villes de Gaule: Le temps des oppida. Lacapelle-Marival: Éditions Archéologie nouvelle.

Filippini, A. (2015). La métallurgie du fer dans le centre-est de la France au $V^{e}$ siècle avant J.-C: Approches historique, archéologique et archéométrique. Bourges/Tours: Bituriga Monographie.

Fletcher, R. (2012). Low-density, agrarian-based urbanism: Scale, power, and ecology. In M. E. Smith (Ed.), The comparative archaeology of complex societies (pp. 285-320). New York: Cambridge University Press.

Frankenstein, S., \& Rowlands, M. J. (1978). The internal structure and regional context of Early Iron Age society in southwestern Germany. Bulletin of the Institute of Archaeology, 15, 73-112.

Gerritsen, F., \& Roymans, N. (2006). Central places and the construction of tribal identities: The case of the Late Iron Age Lower Rhine region. In C. Haselgrove (Ed.), Celtes et Gaulois: l'Archéologie face à l'Histoire. 4: Les mutations de la fin de l'âge du Fer (pp. 251-266). Collection Bibracte 12/4, Glux-en-Glenne.

Gersbach, E. (1995). Baubefunde der Perioden IVc-IVa der Heuneburg. Römisch-Germanische Forschungen, 53. Mainz: Philipp von Zabern.

Gersbach, E. (1996). Baubefunde der Perioden IIIb-Ia der Heuneburg. Römisch-Germanische Forschungen, 56. Mainz: Philipp von Zabern.

Gosden, C. (1985). Gifts and kin in Early Iron Age Europe. Man, 20, 475-493.

Hansen, L., \& Pare, C. (2016). Untersuchungen im Umland des Glaubergs: Zur Genese und Entwicklung eines frühlatènezeitlichen Fürstensitzes in der östlichen Wetterau. Materialien zur Vor- und Frühgeschichte von Hessen 28. Wiesbaden: Landesamt für Denkmalpflege Hessen.

Herrmann, F.-R. (2005). Glauberg: Olympia des Nordens oder unvollendete Stadtgründung?. In J. Biel \& D. Krausse (Eds.), Frühkeltische Fürstensitze: Älteste Städte und Herrschaftszentren nördlich der Alpen? (pp. 18-27). Archäologische Informationen aus Baden-Württemberg, 51. Esslingen: Verlag des Landesamtes für Denkmalpflege.

Johnson, A. W., \& Earle, T. (2000). The evolution of human societies: From foraging group to agrarian state. Stanford: Stanford University Press. 
Karl, R. (2015). Labour procurement in pre-monetary Europe. In A. Danielisova \& M. Fernández-Götz (Eds.), Persistent economic ways of living: Production, distribution, and consumption in late prehistory and early history (pp. 21-36). Budapest: Archaeolingua.

Kimmig, W. (1969). Zum problem späthallstättischer Adelssitze. In K.-H. Otto \& J. Herrmann (Eds.), Siedlung, Burg und Stadt: Studien zu ihren Anfängen (pp. 95-113). Berlin: Deutsche Akademie der Wissenschaften zu Berlin.

Kimmig, W. (1983). Die griechische Kolonisation im westlichen Mittelmeergebiet und ihre Wirkung auf die Landschaften des westlichen Mitteleuropa. Jahrbuch RGZM, 30, 5-78.

Krausse, D. (2006). Prunkgräber der nordwestalpinen Späthallstattkultur: Neue Fragestellungen und Untersuchungen zu ihrer sozialhistorischen Deutung. In C. von Carnap-Bornheim, D. Krausse \& A. Wesse (Eds.), Herrschaft-Tod-Bestattung: Zu den vor- und frühgeschichtlichen Prunkgräbern als archäologisch-historische Quelle (pp. 61-80). Bonn: Habelt.

Krausse, D. (Ed.) (2008a). Frühe Zentralisierungs- und Urbanisierungsprozesse: Zur Genese und Entwicklung frühkeltischer Fürstensitze und ihres territorialen Umlandes. Forschungen und Berichte zur Vor- und Frühgeschichte in Baden-Württemberg, 101. Stuttgart: Konrad Theiss.

Krausse, D. (2008b). Etappen der Zentralisierung nördlich der Alpen: Hypothesen, Modelle, Folgerungen. In D. Krausse (Ed.), Frühe Zentralisierungs- und Urbanisierungsprozesse: Zur Genese und Entwicklung frühkeltischer Fürstensitze und ihres territorialen Umlandes (pp. 435-450). Forschungen und Berichte zur Vor- und Frühgeschichte in Baden-Württemberg, 101: Stuttgart: Konrad Theiss.

Krausse, D. (Ed.) (2010). „Fürstensitze“ und Zentralorte der frühen Kelten. Forschungen und Berichte zur Vor- und Frühgeschichte in Baden-Württemberg, 120. Stuttgart: Konrad Theiss.

Krausse, D., Ebinger-Rist, N., Million, S., Billamboz, A., Wahl, J., \& Stephan, E. (2017). The 'Keltenblock' project: Discovery and excavation of a rich Hallstatt grave at the Heuneburg, Germany. Antiquity, 91(355), 108-123.

Krausse, D., Fernández-Götz, M., Hansen, L., \& Kretschmer, I. (2016). The Heuneburg and the Early Iron Age princely seats: First towns north of the Alps. Budapest: Archaeolingua.

Kristiansen, K. (1998). Europe before history. Cambridge: Cambridge University Press.

Kurz, S. (2010). Zur Genese und Entwicklung der Heuneburg in der späten Hallstattzeit. In D. Krausse (Ed.), „Fürstensitze” und Zentralorte der frühen Kelten (pp. 239-256). Forschungen und Berichte zur Vor- und Frühgeschichte in Baden-Württemberg, 120. Stuttgart: Konrad Theiss.

Metzner-Nebelsick, C. (2009). Wagen- und Prunkbestattungen von Frauen der Hallstatt- und frühen Latènezeit in Europa. In J. M. Bagley, C. Eggl, D. Neumann, \& M. Schefzik (Eds.), Alpen, Kult und Eisenzeit: Festschrift für Amei Lang (pp. 237-270). Rahden/Westf: Verlag Marie Leidorf.

Milcent, P.-Y. (2003). Le contexte historique. In C. Rolley (Ed.), La tombe princière de Vix (pp. 327-366). Paris: Picard.

Milcent, P.-Y. (2004). Le premier âge du Fer en France centrale. 2 vols. Paris: Mémoire de la Soc prehist Fr 35.

Milcent, P.-Y. (Ed.). (2007). Bourges-Avaricum: Un centre proto-urbain celtique du $V^{e}$ s. av. J.-C. Tours/ Bourges: Bituriga.

Milcent, P.-Y. (2014). Hallstatt urban experience before the Celtic oppida in Central and Eastern Gaul. Two Cases-Studies: Bourges and Vix. In M. Fernández-Götz, H. Wendling \& K. Winger (Eds.), Paths to complexity: Centralisation and urbanisation in Iron Age Europe (pp. 35-51). Oxford: Oxbow Books.

Nakoinz, O. (2013). Archäologische Kulturgeographie der ältereisenzeitlichen Zentralorte Südwestdeutschlands. Bonn: Habelt.

Ortman, S. G., Cabaniss, A. H. F., Sturm, J. O., \& Bettencourt, L. M. A. (2014). The pre-history of urban scaling. PLoS ONE, 9, 1-10.

Perrin, F., \& Bellon, C. (1997). L'occupation du premier Âge du Fer des bords de la Saône à Lyon. In P. Brun \& B. Chaume (Eds.), Vix et les éphémères principautés celtiques (pp. 157-164). Paris: Errance.

Ralston, I. (2007). Bourges and the Earlier Iron Age: An interim view. In P. de Jersey, C. Gosden, H. Hamerow, \& G. Lock (Eds.), Communities and connections: Essays in honour of Barry Cunliffe (pp. 217-239). Oxford: Oxford University Press.

Ralston, I. (2010). Fragile states in mid-first millennium BC temperate Western Europe? The view from Bourges. Social Evolution \& History, 9(2), 135-159.

Rolley, C. (Ed.). (2003). La tombe princière de Vix. Paris: Picard.

Schumann, R. (2015). Status und Prestige in der Hallstattkultur. Rahden/Westf: Verlag Marie Leidorf. 
Sievers, S., \& Schönfelder, M. (Eds.). (2012). Die Frage der Protourbanisation in der Eisenzeit. La question de la proto-urbanisation à l'âge du Fer. Bonn: Habelt.

Smith, M. E. (2014). Foreword. In M. Fernández-Götz, H. Wendling \& K. Winger (Eds.), Paths to complexity: Centralisation and urbanisation in Iron Age Europe (pp. v-vi). Oxford: Oxbow Books.

Smith, M. E. (2016). How can archaeologists identify early cities? Definitions, types, and attributes. In M. Fernández-Götz \& D. Krausse (Eds.), Eurasia at the dawn of history: Urbanization and social change (pp. 153-168). New York: Cambridge University Press.

Stegmaier, G. (2016). The Heuneburg: A centre of pottery production. In D. Krausse, M. Fernández-Götz, L. Hansen, \& I. Kretschmer (Eds.), The Heuneburg and the Early Iron Age princely seats: First towns north of the Alps (pp. 88-90). Budapest: Archaeolingua.

Verger, S. (2006). La grande tombe de Hochdorf, mise en scène funéraire d'un cursus honorum tribal hors pair. Siris, 7, 5-44.

Verger, S. (2009). Société, politique et religion en Gaule avant la Conquête: Éléments pour une étude anthropologique. Pallas, 80, 61-82.

Verger, S. (2015). L'Âge du Fer ancien: l'Europe moyenne avant les Celtes historiques (800-400). In O. Buchsenschutz (Ed.), L'Europe celtique à l'âge du Fer (VIII $-I^{e r}$ siècle) (pp. 75-176). Paris: PUF.

Verger, S., \& Osanna, M. (Eds.). (2010). Palais en Méditerranée, de Mycènes aux Tarquins: Les dossiers d'archéologie, 339. Dijon: Faton.

Wallerstein, I. (1974). The modern world-system I: Capitalist agriculture and the origins of the European world-economy in the 16th century. New York: Academic Press. 